\title{
Updates on the geographic distribution of three Geastrum species from Brazilian semi-arid region
}

\author{
Sousa $\mathrm{JO}^{1}$, Morais $\mathrm{LA}^{2}$, Nascimento $\mathrm{YM}^{2}$ and Baseia $\mathrm{IG}^{3}$ \\ ${ }^{1}$ Programa de Pós-graduação em Sistemática e Evolução, Universidade Federal do Rio Grande do Norte, Campus \\ Universitário, 59072-970, Natal, Rio Grande do Norte, Brazil, julieth.oliveira.sousa@gmail.com \\ ${ }^{2}$ Curso de Graduação em Ciências Biológicas, Universidade Federal do Rio Grande do Norte, Campus Universitário, \\ 59072-970, Natal, Rio Grande do Norte, Brazil \\ ${ }^{3}$ Departamento de Botânica e Zoologia, Universidade Federal do Rio Grande do Norte, Campus Universitário, 59072- \\ 970, Natal, Rio Grande do Norte, Brazil
}

Sousa JO, Morais LA, Nascimento YM, Baseia IG 2014 - Updates on the geographic distribution of three Geastrum species from Brazilian semi-arid region. Mycosphere 5(3), 467-474, Doi 10.5943/mycosphere/5/3/9

\begin{abstract}
Taxonomic studies on Brazilian semi-arid collections of earthstars revealed the occurrence of three species: Geastrum floriforme (first record for Brazil), Geastrum violaceum (new for the tropical region) and Geastrum xerophilum (second record for the Neotropics). Detailed basidiomata descriptions with taxonomic remarks, photos and drawings of macro- and micro-morphological data are given.
\end{abstract}

Key words - gasteromycetes - Geastrales — neotropical fungi - taxonomy

\section{Introduction}

Earthstars are fungi belong to the family Geastraceae (Phallomycetidae, Basidiomycota) and are distributed in two genera: Geastrum Pers. and Myriostoma Desv., both characterized by gasteroid basidiomata, which are star-shaped when mature, and passively released by the bellows mechanism (Sunhede 1989, Hemmes \& Desjardin 2011, Jeppson et al. 2013). Geastrum is one of the most diversified gasteroid genera, with a cosmopolitan distribution, and may be found in a wide range of habits (Kuhar \& Papinutii 2009, Zamora et al. 2013).

Despite recent publications with new species of earthstars, such as Geastrum setiferum Baseia (Baseia \& Milanez 2003), G. hirsutum Baseia \& Calonge (Baseia \& Calonge 2006), G. entomophilum Fazolino, Calonge \& Baseia (Fazolino et al. 2008), G. aculeatum B.D.B. Silva \& Baseia, G. echinulatum T.S. Cabral, B.D.B. Silva \& Baseia (Silva et al. 2013) and G. rusticum Baseia, B.D.B. Silva \& T.S. Cabral (Cabral et al. 2014), taxonomic studies and systematic phylogenetic analysis of the genus Geastrum in the Neotropics remain scarce, especially in the semi-arid areas of Brazil (Drechsler-Santos et al. 2008, Silva et al. 2011, 2013).

The semi-arid region, which covers $13 \%$ of the country, is characterized by water deficiency, high temperatures and xerophytic vegetation. This region contains distinct phyto-physiognomies such as Atlantic Rainforest enclaves, popularly known as "Brejos de Altitude" and the Caatinga, an exclusively Brazilian plant domain, which shelters high biodiversity and is submitted to intense anthropic pressures (Sá et al. 2004, Leal et al. 2005). 
This study aims at widening knowledge on species richness and distribution of the genus Geastrum in the semi-arid region of Brazil.

\section{Materials \& Methods}

The descriptions are based on specimens deposited in the semi-arid collection of the Herbarium of the Federal University of Rio Grande do Norte (UFRN Herbarium). Specimens were collected in the rainy season of 2007 in the Parque Nacional Vale do Catimbau $\left(8^{\circ} 37^{\prime} 0^{\prime \prime} \mathrm{S}, 37^{\circ} 9^{\prime} 0^{\prime \prime} \mathrm{W}\right)$ - Caatinga vegetation, and during the rainy season of 2013 in the Reserva Ecológica Mata do Pau Ferro (6 $6^{\circ} 58^{\prime} 12^{\prime \prime}$ S, 35 42' 15" W) - "Brejo de Altitude". Both collection sites are located in semi-arid northeastern Brazil. Macro and microscopical studies were conducted with dry basidiomata and according to procedures described in the literature (Ponde de Leon 1968, Sunhede 1989, Calonge 1998, Bates 2004). Color descriptions followed Kornerup \& Wanscher (1978). Taxonomic nomenclature was based in Kirk et al. (2008). For light microscopy, free-hand sections were mounted in 5\% (w/v) $\mathrm{KOH}$. Thirty randomly selected basidiospores were measured using light microscopy (LM), and all measurements included surface ornamentation. Scanning electron microscopy (SEM) was performed for meticulous observations of the ornamentation patterns of basidiospores and capillitium, surface. Preparation of the material examined under SEM followed Silva et al. (2011). Statistical measurements used in basidiospore analysis were in accordance with Bates (2004), where " $n$ " corresponds to the number of randomly measured basidiospores, " $x$ " is the mean width and basidiospore length, " \pm " is the standard deviation and "Qm" the quotient between mean width and length.

\section{Results}

Geastrum floriforme Vittad., Monographia Lycoperdineorum 23 (1842) Plate 1, Figure 1A Expanded basidioma saccate, $12 \mathrm{~mm}$ high $\times 10 \mathrm{~mm}$ wide. Exoperidium splitting into 9 rays, involute, entirely covering the endoperidial body, some rays splitting at tips, strongly hygroscopic. Mycelial layer ephemeral, with some remnants on the fibrous layer. Fibrous layer light orange (5A2), coriaceous. Pseudoparenchymatous layer brown (6F4), glabrous, persistent. Endoperidium depressed globose, $6 \mathrm{~mm}$ high $\times 9 \mathrm{~mm}$ wide, sessile, surface furfuraceuos, brown (6E4). Apophysis and stalk absent. Peristome fibrillose, becoming lacerate with age, not delimitated, mammiform (up to $1 \mathrm{~mm}$ high), concolorous with endoperidium. Gleba yellowish brown (5E4).

Basidiospores globose to subglobose, 4.8-7.1 $\times$ 4.6-6.8 $\mu \mathrm{m}[x=6 \pm 0.7 \times 5.8 \pm 0.6, \mathrm{Qm}=$ $1.02, \mathrm{n}=30$ ], yellowish brown, warts evident under LM. Densely verrucose under SEM; warts irregular, strongly truncate with planar or confluent tips; apiculus not seen. Capillitium 3.6-5.1 $\mu \mathrm{m}$ diam., walls straight, thin $(<1 \mu \mathrm{m}$ diam.), surface not encrusted, glabrous lumen evident, not branched, yellowish. Mycelial layer absent. Fibrous layer composed of thick-walled hyphae (> 1 $\mu \mathrm{m})$, 3.5-7 $\mu \mathrm{m}$ diam., surface not encrusted, lumen evident, hyaline to yellowish. Pseudoparenchymatous layer composed of thick-walled $(<1 \mu \mathrm{m})$ hyphal cells, subglobose 12.6$33.6 \mu \mathrm{m}$ diam., hyaline to yellowish.

Known distribution - Africa: South Africa (Bottomley 1948). North America: United States (Bates 2004); Mexico (Esqueda et al. 1995, 2009). South America: Argentina (Soto \& Wright 2000; Kuhar et al. 2012). Asia: China (Liu 1984). Europe: Spain (Calonge 1998); Finland (Sunhede 1989); England (Pegler et al.1995); Sweden (Sunhede, 1989; Carlsson et al. 2008; Jeppson et al. 2013). Hawaii (Hemmes \& Desjardin 2011). Oceania: Australia (Grgurinovic 1997); New Zealand (Cunningham 1944).

Material examined - Brazil, Pernambuco, Buíque, Parque Nacional Vale do Catimbau, growing on soil, 21 Jul 2007, T.B.S. Ottoni, UFRN Fungos - 1278.

Geastrum violaceum Rick, Brotéria 5: 26 (1906)

Plate 2, Figure 1B

$=$ Geastrum episcopale F. Kuhar \& L. Papinutti, Mycologia 101: 535 (2009)

Expanded basidiomata saccate, 12-25 $\mathrm{mm}$ high $\times 9-26 \mathrm{~mm}$ wide, rhizomorphs attached, 


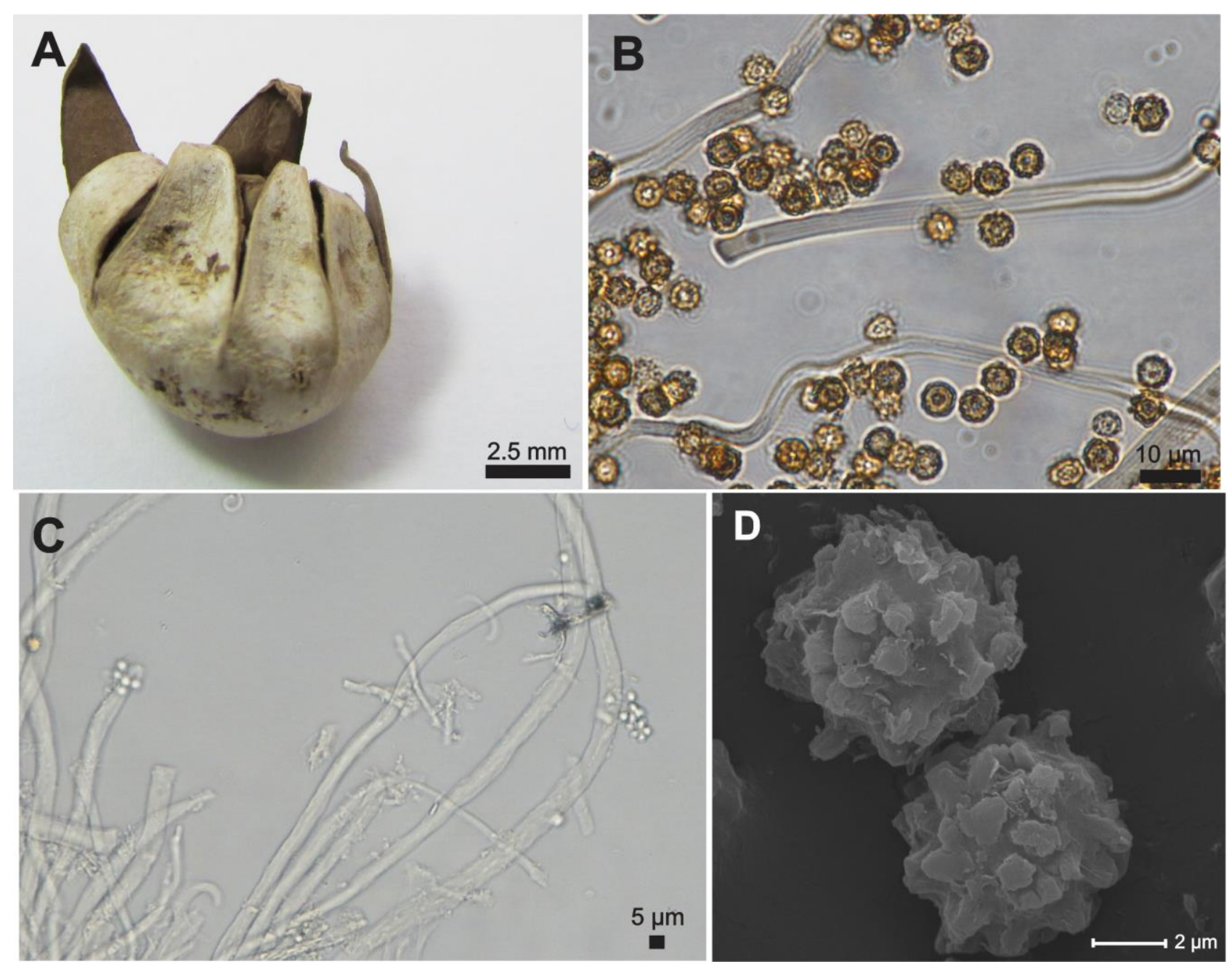

Plate 1 -Geastrum floriforme. A Expanded basidioma. B Basidiospores and capillitium under LM. C Hyphae from fibrous layer under LM. D Basidiospores under SEM.

often slightly stipitate. Exoperidium splitting into 6-9 rays, revolute, rolling up under basidioma, non-hygroscopic. Mycelial layer dark purple (14F4) to greyish magenta (13E4), papery to felted, surface not encrusted, with longitudinal cracks. Fibrous layer yellowish white (4A2), papery. Pseudoparenchymatous layer greyish ruby (12D5) when fresh, greyish magenta (13E5) to dark magenta (13F4) when dry, glabrous, often forming a collar-like structure surrounding the endoperidium. Endoperidium subglobose to pyriform, 5-17 mm high $\times 5-12 \mathrm{~mm}$ wide, sessile, surface glabrous, violet brown (10F8) when fresh, greyish brown (10F3) when dry. Apophysis and stalk absent. Peristome irregularly plicate, becoming fibrillose to lacerate with age, not delimited, conic (up to $2 \mathrm{~mm}$ high), $4-9$ folds, lighter than the endoperidium. Gleba brownish grey (5C2).

Basidiospores globose, 2.9-3.1 $\times 2.7-3.0 \mu \mathrm{m}[x=3.1 \pm 0.2 \times 3.0 \pm 0.2, \mathrm{Qm}=1.02, \mathrm{n}=30]$, brownish, warts inconspicuous under LM. Finely verrucose under SEM; warts short with rounded tips; apiculus evident, surrounded by short processes. Capillitium 4.6-7.1 $\mu \mathrm{m}$ diam., walls straight, thick ( $>1 \mu \mathrm{m}$ diam.), surface light encrusted, glabrous, lumen evident, not branched, brownish. Mycelial layer composed of sinuous thin-walled hyphae $(<1 \mu \mathrm{m}), 2.9-4.6 \mu \mathrm{m}$ diam., surface not encrusted, lumen pinkish, branched, hyaline. Fibrous layer composed of sinuous hyphae, 3.7-5.2 $\mu \mathrm{m}$ diam., surface light encrusted, lumen not evident, hyaline. Pseudoparenchymatous layer composed of thick-walled $(<1 \mu \mathrm{m})$ hyphal cells, globose, subglobose, pyriform to oval, 47-82 $\mu \mathrm{m}$ in length $\times 7.4-57 \mu \mathrm{m}$ in wide, hyaline with pinkish granules.

Known distribution - South America: Brazil, Rio Grande do Sul state (Rick 1961, Trierveiler-Pereira \& Silveira 2012); Argentina (Kuhar \& Pappinuti 2009).

Material examined - Brazil, Paraíba, Areia, Parque Estadual Mata do Pau Ferro, growing on litter, 15 Jul 2013, J.O. Sousa, D.S. Alfredo \& R.A. Lima, JM31, UFRN Fungos - 2117, 
0658'51.5”S, 3544'43.5”W, 600 a.s.1, 18 Jul 2013, J.O. Sousa, D.S. Alfredo \& R.A. Lima, JM56, UFRN Fungos - 2118.
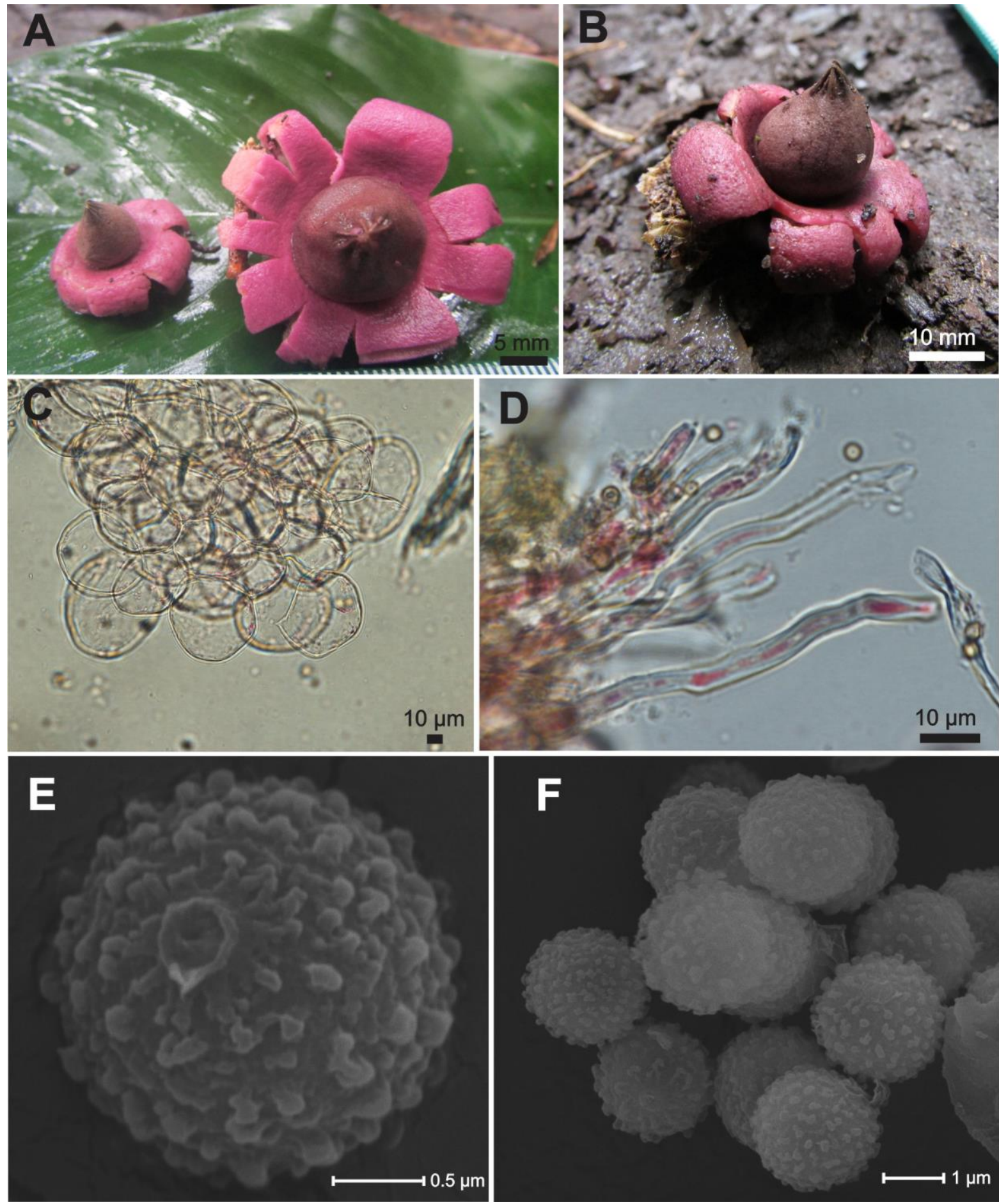

Plate 2 - Geastrum violaceum. A, B Expanded basidiomata. C Hyphal cells from pseudoparenchymatous layer under LM (with pinkish granules and thick-walled). D Hyphae from mycelial layer under LM. E, F Basidiospores SEM.

Geastrum xerophilum Long ex Desjardin, Pacific Science 65:493 (2011)

Plate 3, Figure 1C

Expanded basidiomata saccate to arched, 5-19 mm high $\times 5-24 \mathrm{~mm}$ wide. Exoperidium splitting into 6-11 rays, arched to involute, rolling up under endoperidial body, some rays broken off, semi hygroscopic. Mycelial layer brown (6E5) to grayish orange (5B3, 5B4), papery to felted, surface totally encrusted with sand, persistent. Fibrous layers orange white (5A2) brownish orange (5C5), papery. Pseudoparenchymatous layer brown (6E6) to dark brown (6F4, 6F6), surface 
rimose, persistent. Endoperidium depressed globose to subglobose, 2-11 mm high $\times 4-12 \mathrm{~mm}$ wide, stalked, surface furfuraceous, becoming glabrous with age, pale orange (5A3), orange gray (5B2) or brownish gray (6D3, 6D6, 6E3). Apophysis reduced, concolorous with the endoperidium. Stalk reduced (up to $1 \mathrm{~mm}$ high), lighter than endoperidium. Peristome plicate, becoming lacerated with age, not delimitated, conic (up to $2.5 \mathrm{~mm}$ high), 14-35 folds, concolorous or darker than endoperidium. Gleba grayish brown (5F3) to yellowish brown (5E5).

Basidiospores globose to subglobose, 4.4-6.3 $\times 4.1-6.3 \mu \mathrm{m}[x=5.4 \pm 0.5 \times 5.3 \pm 0.4, \mathrm{Qm}=$ $1.02, \mathrm{n}=30]$, yellowish, warts evident under LM. Densely verrucose under SEM; warts long, triangular, often with truncate tips, apiculus not seen. Capillitium 3-5 $\mu \mathrm{m}$ diam., walls sinuous, thick ( $>1 \mu \mathrm{m}$ diam.), surface not encrusted, glabrous, lumen not evident, not branched, yellowish. Mycelial layer composed of sinuous thin-walled hyphae $(<1 \mu \mathrm{m}), 2-4.5 \mu \mathrm{m}$ diam., surface not encrusted, lumen not evident, branched, hyaline to yellowish. Fibrous layer composed of sinuous to straight thick-walled hyphae $(>1 \mu \mathrm{m}), 2-6.1 \mu \mathrm{m}$ diam., surface not encrusted, lumen often evident, hyaline to bronwish. Pseudoparenchymatous layer composed of thin-walled $(<1 \mu \mathrm{m})$ hyphal cells, elongate to oval, 12.9-47.9 in length $\times 9-28 \mu \mathrm{m}$ in wide, hyaline to yellowish.

Known distribution - North America: United States (Ponce de Leon 1968, Bates 2004); Mexico (Esqueda et al. 1995, 2009, Moreno et al. 2010); South America: Brazil, Rio Grande do Norte state (Silva et al. 2011); Europe: Spanish (Jeppson et al. 2013); Hawaii (Smith \& Ponce de Leon 1982, Gilbertson et al. 2001, Hemmes \& Desjardin 2011).

Material examined - Brazil, Pernambuco, Buíque, Parque Nacional Vale do Catimbau, growing on soil, 21 Jul 2007, T. B. S. Ottoni, UFRN Fungos - 334, 21 Jul 2007, T. B. S. Ottoni,

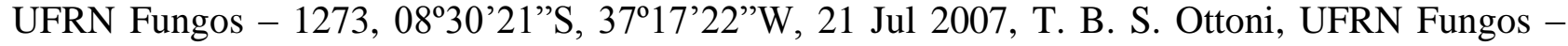
1275, 22 Jul 2007, T. B. S Ottoni, UFRN Fungos - 944, 08³0’34’'S, 37²16’50”W, 23 Jul 2007, T. B. S Ottoni, UFRN Fungos - 943; 23 Jul 2007, T. B. S Ottoni, UFRN Fungos - 1279.

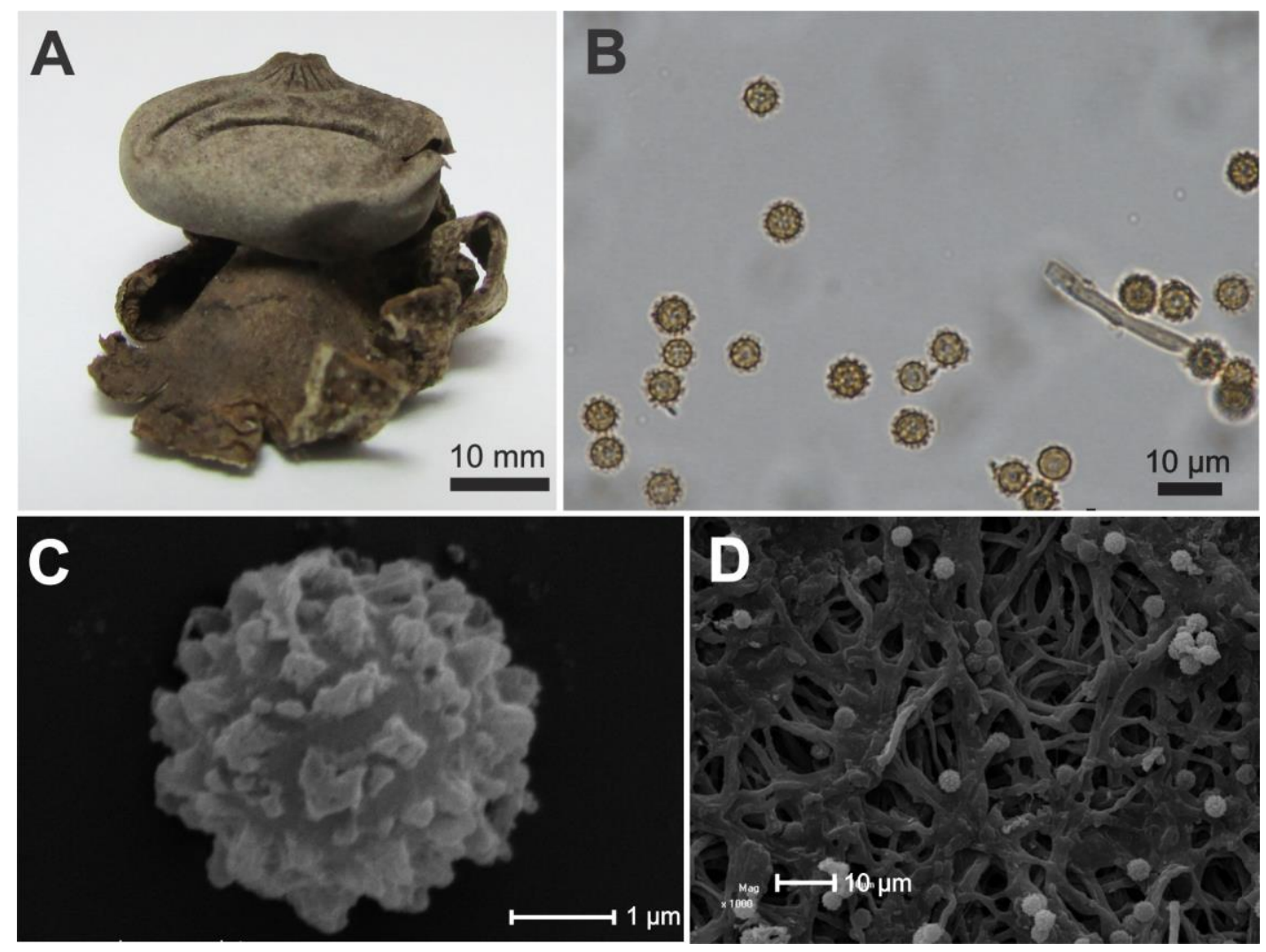

Plate 3 - Geastrum xerophilum. A Expanded basidioma. B Basidiospores under LM. C Basidiospore under SEM. D Surface of endoperidium under SEM. 
A

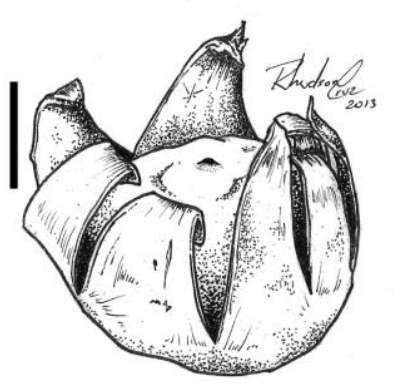

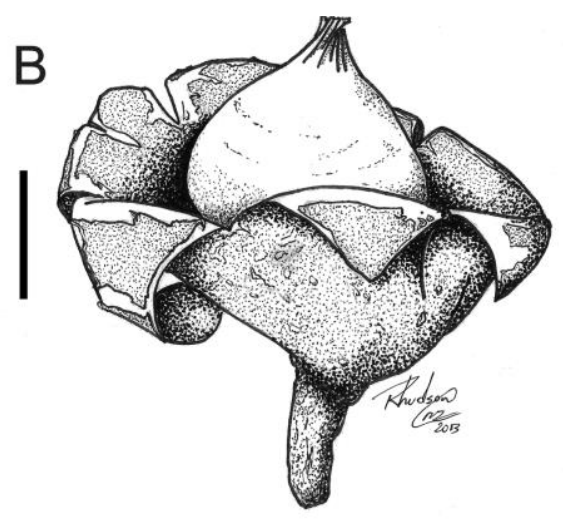

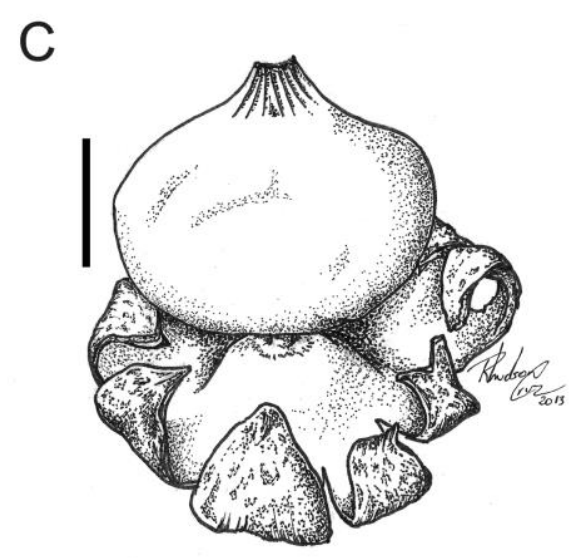

Figures 1 - Schematic drawing of expanded basidiomata. A Geastrum floriforme. B G. violaceum. C G. xerophilum. Scale bars $=5 \mathrm{~mm}$.

\section{Discussion}

Geastrum floriforme is truly hygroscopic specie, with rays entirely covering the endoperidial body. It also characterized by fibrillose peristome, undelimited and endoperidium sessile furfuraceous, in addition, mycelial layer is often absent on expanded specimens (Sunhede 1989, Bates 2004, Hemmes \& Desjardin 2011). Although Geastrum hungaricum Hollós exhibits morphology similar to G. floriforme in the presence of hygroscopic rays, a fibrillose peristome and a mycelial layer encrusted with sediment, it differs in its distinctly delimited peristome, pruinose endoperidium and smaller basidiomata (Sunhede 1989). Geastrum corollinum (Batsch) Hollós and Geastrum kotlabae V.J. Staněk also exhibit strongly hygroscopic rays, a trait observed in species occurring in dry environments (Jeppson et al. 2013). However, Geastrum corollinum differs from G. floriforme by its distinctly delimited peristome, mycelial layer free of encrustations, and smaller basidiospores (up to $5 \mu \mathrm{m}$ in diameter). Geastrum kotlabae can be segregated due to its plicate peristome and verrucose endoperidium (Sunhede 1989, Pegler et al. 1995, Calonge 1998, Bates 2004). Geastrum floriforme is widely distributed, and this is the first record for Brazil.

Geastrum violaceum displays distinct coloring, differing from the color pattern of other species of Geastrum, ranging from black to reddish. It can clearly be distinguished from the other species, as it exhibits a pinkish to reddish exoperidium and endoperidium, undelimited peristome, irregularly plicate and small basidiospores measuring up to $3.2 \mu \mathrm{m}$ (Lloyd 1907, Kuhar \& Papinutii 2009, Trierveiler-Pereira \& Silveira 2012). Another peculiarity of G. violaceum is the presence of a small stipe, under the basidioma, a trait observed in few species of the genus, such as Geastrum schweinitzii var. stipitatum (Solms) P. Ponce de León, which differs from G. violaceum in its distinctly delimited fibrillose peristome and presence of subiculum (Ponce de Léon 1968, Sunhede 1989). According to Rick (1961), G. violaceum differs from Geastrum saccatum Fr. only in the pinkish color of the exoperidium. However, G. saccatum can be also distinguished by its delimited fibrillose peristome and larger basidiospores (4.5-6 $\mu \mathrm{m})$ (Sunhede 1989, Kuhar \& Papinutii 2009). Geastrum morganii Lloyd and G. violaceum are very similar species morphologically, both with basidiomata saccate, peristome irregularly plicate, not delimited, mycelial layer free of encrustations and endoperidium sessile (Kuhar \& Papinutii 2009, Zamora et al. 2013), but $G$. morganii can be easily distinguished by its brownish exoperidium and larger basidiospores (4.5-6 $\mu \mathrm{m}$ ) (Sunhede 1989). To date the occurrence of this species has been restricted to subtropical ecosystems, this being the first record of Geastrum violaceum for the tropics and the first for the semi-arid region of Brazil.

Geastrum xerophilum is not truly hygroscopic specie, with rays rolling up under endoperidial body. Other main characteristics are plicate peristome, undelimited, endoperidium pedicellate with surface furfuraceous and basidiospores densely verrucose. This specie has hypogeous habit when unexpanded, hence it has mycelial layer strongly encrusted with sediment on expanded specimens. 
Morphologically, this species is similar to Geastrum campestre Morgan and G. kotlabae, both exhibiting a plicate peristome, hypogeous basidiomata and exoperidium encrusted with sediment. On the other hand, G. campestre and G. kotlabae differ from G. xerophilum in thier strongly hygroscopic rays and verrucose exoperidium. One peculiarity of Geastrum xerophilum is its occurrence strictly in dry environments (Silva et al. 2011, Jeppson et al. 2013), this being the first record for the semi-arid region of Pernambuco state and the second record of the species for the Neotropics.

\section{Acknowledgements}

The authors gratefully acknowledge CAPES (Conselho de Aperfeiçoamento de Pessoal de Nível Superior, Brazil) and Conselho Nacional de Desenvolvimento Científico e Tecnológico (CNPq) for providing a scholarship, and the Semi-Arid Biodiversity Research Program (PPBio Semiárido/CNPq) for financial support. The authors would also like to thank Rhudson Cruz for the drawings and Professor Vagner Gularte Cortez (UFPR, Campus Palotina) for kindly help with SEM analyses.

\section{References}

Baseia IG, Milanez AI. 2003 - Geastrum setiferum (Gasteromycetes): a new species with a setose endoperidium. Mycotaxon 84, 135-140.

Baseia IG, Calonge FD. 2006 - Geastrum hirsutum: a new earthstar fungus with a hairy exoperidium. Mycotaxon 95: 301-304.

Bates ST. 2004 - Arizona members of the Geastraceae and Lycoperdaceae (Basidiomycota, Fungi). Master Thesis, Arizona State University, U.S.A.

Bottomley AM. 1948 - Gasteromycetes of South Africa. Bothalia 4, 473-810.

Cabral TS, Silva BDB, Marinho P, Baseia IG. 2014 - Geastrum rusticum (Geastraceae, Basidiomycota), a new earthstar fungus in the Brazilian Atlantic rainforest - a molecular analysis. Nova Hedwigia 98 (1 -2), 265-272.

Calonge FD. 1998 - Gasteromycetes: Lycoperdales, Nidulariales, Phallales, Sclerodermatales, Tulostomatales. Flora Micológica Ibérica 3, 271 pp.

Carlsson RG, Johansson N, Johansson KA. 2008 - Blomjordstjärna (Geastrum floriforme) funnen i Västergötland. Svensk Mykologisk Tidskrift 29 (2), 74-79.

Cunningham C H. 1944 - The Gasteromycetes of Australia and New Zealand. Dunedin 236.

Drechsler-Santos ER, Wartchow F, Baseia IG, Gibertoni TB, Cavalcanti MAQ. 2008- Revision of the Herbarium URM I. Agaricomycetes from the semi-arid region of Brazi. Mycotaxon 104, 9-18.

Esqueda M, Pérez-Silva E, Herrera T. 1995 - New records of gasteromycetes for Mexico. Documents Mycologiques 25(98-100), 151-160.

Esqueda M, Sánchez A, Rivera M, Coronado ML, Lizárraga M, Valenzuela R. 2009 - Primeros registros de hongos gasteroides en la Reserva Forestal Nacional y Refugio de Fauna Silvestre Ajos-Bavispe, Sonora, Mexico. Revista Mexicana de Micología 30, 19-29.

Fazolino EP, Calonge FD, Baseia IG. 2008 - Geastrum entomophilum, a new earthstar with an unusual spore dispersal strategy. Mycotaxon 104, 449-453.

Hemmes DE, Desjardin DE. 2011 - Earthstars (Geastrum, Myriostoma) of the Hawaiian Islands including two new species, Geastrum litchiforme and Geastrum reticulatum. Pacific Science $65,477-496$.

Gilbertson RL, Desjardin DE, Rogers JD, Hemmes DE. 2001 - Fungi from the Mamane-Naio vegetation zone of Hawaii. Fungal Diversity 6, 35-69.

Grgurinovic AC. 1997 - Larger Fungi of South Australia. Adelaide: Botanic Gardens of Adelaide and State Herbarium and Flora and Fauna of South Australia Handbooks Committee 6, 765. 
Jeppson M, Nilsson HR, Larsson E. 2013 - European earthstars in Geastraceae (Geastrales, Phallomycetidae) - a systematic approach using morphology and molecular sequence data. Systematics and Biodiversity 11 (4), 437-465.

Kornerup A, Wansher JE. 1978 - Methuen handbook of colour, 3rd edn., London: Methuen.

Kirk PM, Cannon PF, Minter DW, Stalpers JA. 2008 - Dictionary of the Fungi. 10rd Edition. CAB International, Wallinford. 771pp.

Kuhar F, Castiglia V, Papinutii L - 2012. Geastrum species of the La Rioja province, Argentina. Mycotaxon 122, 145-164.

Kuhar F, Papinutii L. 2009 - Geastrum episcopale: a new noticeable species with red-violet exoperidium. Mycologia 101 (4), 535-538.

Leal IR, Da Silva, JMC, Tabarelli M, Lacher TE - 2005. Mudando o curdo da conservação da biodiversidade na Caatinga do Nordeste do Brasil. Megadiversidade 1(1), 139-146.

Liu B. 1984 - The Gasteromycetes of China. Beiheftezur. Nova Hedwigia 74, 1-235.

Lloyd GC. 1907 - New notes on the Geasters. Mycological Notes $n^{\circ}$ 25. Mycological Writings 2: 309-317.

Moreno G, Lizárraga M, Esqueda M, Coronado M L. 2010 - Contribution to the study of gasteroid and secotioid fungi of Chihuahua, Mexico. Mycotaxon 112, 291-315.

Pegler DN, Læssøe T, Spooner BM. 1995 - British puffballs, earthstars, and stinkhorns. Royal Botanic Gardens, Kew 79-122.

Ponce de León P. 1968 - A revision of the family Geastraceae. Fieldiana Botany 31, 302-349.

Rick J. 1961 - Basidiomycetes Eubasidii no Rio Grande do Sul. Brasília. Iheringia 9, 451-480.

Sá IB, Riché GR, Fotius GA. 2004 - Biodiversidade da Caatinga: áreas e ações prioritárias para a conservação. Brasilia: MMA-UFPE; Brasília, DF 17-36.

Silva BDB, Cabral TS, Marinho P, Ishikawa NK, Baseia IG. 2013. Two new species of Geastrum (Geastraceae, Basidiomycota) found in Brazil. Nova Hedwigia 96 (3-4), 445-456.

Silva BDB, Sousa JO, Baseia IG. 2011 - Discovery of Geastrum xerophilum from the Neotropics. Mycotaxon 118, 355-358.

Smith CW, Ponce de León P. 1982 - Hawaiian geastroid fungi. Mycologia 74, 712-717.

Soto MK, Wright JE. 2000 - Taxonomia del genero Geastrum ( Basidiomycetes, Lycoperdales) em la provincia de Buenos Aires, Argentina. Boletin de la Sociedad Argentina de Botanica 34 (3-4), 185-201.

Sunhede S. 1989. Geastraceae (Basidiomycotina). Morphology, ecology, and systematics with special emphasis on the North European Species. Synopsis Fungorum 1, 534pp.

Trierveiler-Pereira L, Silveira RMB. 2012 - On the Geastrum species (Geastraceae, Basidiomycota) described by Rick. Phytotaxa 61, 37-46.

Zamora JC, Calonge FD, Martín MP. 2013 - New sources of taxonomic information for earthstars (Geastrum, Geastraceae, Basidiomycota): phenoloxidases and rhizomorph crystals. Phytotaxa $132(1), 1-20$. 